\title{
CORRIGENDUM
}

\section{Cervical spine epidural abscess: a single center analytical comparison to the literature}

Faris Shweikeh, Mohammed Hussain, Ajleeta Sangtani, Husam Issa, Asif Bashir, J Patrick Johnson and Georges Z Markarian

Spinal Cord Series and Cases (2017) 3, 17061; doi:10.1038/scsandc.2017.61; published online 5 October 2017

Correction to: Spinal Cord Series and Cases (2017) 3, 17036; doi:10.1038/scsandc.2017.36; published online 6 July 2017

The original version of the article was published with errors. This has now been updated and the corrections have been implemented in the original article.
The author apologises for any inconvenience caused by this error. 